\title{
The distribution of vitamin $A$ and retinol-binding protein in the blood plasma, urine, liver and kidneys of carnivores
}

\author{
Jens RAILA ${ }^{\text {a* }}$, Ingeborg BuCHHOLZ ${ }^{\mathrm{b}}$, Heike AUPPERLE ${ }^{\mathrm{c}}$, \\ Gerit RAILA ${ }^{\mathrm{c}}$, Heinz-Adolf SCHOON ${ }^{\mathrm{c}}$, Florian J. SCHWEIGERT ${ }^{\mathrm{a}}$ \\ ${ }^{a}$ Institute of Nutritional Science, University Potsdam, Arthur-Scheunert-Allee 114-116, \\ 14558 Potsdam-Rehbrücke, Germany \\ ${ }^{b}$ Department of Physiology, University Leipzig, Veterinary Faculty, An den Tierkliniken 7, \\ 04103 Leipzig, Germany \\ ${ }^{c}$ Institute of Veterinary-Pathology, University Leipzig, Veterinary Faculty, \\ An den Tierkliniken 33, 04103 Leipzig, Germany
}

(Received 10 January 2000; accepted 27 June 2000)

\begin{abstract}
The contents of retinol and retinyl esters as well as retinol-binding protein (RBP) in the plasma, urine, liver and kidneys of dogs, raccoon dogs and silver foxes were investigated. In the plasma and urine of all three species, vitamin A was present as retinol and retinyl esters. Vitamin A levels $\left(1376 \pm 669 \mu \mathrm{g} \cdot \mathrm{g}^{-1}\right)$ were significantly higher in the livers of dogs than in the kidneys $\left(200 \pm 217 \mu \mathrm{g} \cdot \mathrm{g}^{-1}, P<0.001\right)$. However, vitamin A levels in the kidneys of raccoon $\operatorname{dogs}$ $\left(291 \pm 146 \mu \mathrm{g} \cdot \mathrm{g}^{-1}\right)$ and silver foxes $\left(474 \pm 200 \mu \mathrm{g} \cdot \mathrm{g}^{-1}\right)$ were significantly higher than in the liver $\left(67 \pm 58 \mu \mathrm{g} \cdot \mathrm{g}^{-1}\right.$ and $4.3 \pm 2.4 \mu \mathrm{g} \cdot \mathrm{g}^{-1}$, respectively, both $\left.P<0.001\right)$. RBP was immunologically detected in the blood plasma of all species, but never in the urine. In the liver, immunoreactive RBP was found in hepatocytes. In the kidneys of all species, RBP was observed in the cells of the proximal convoluted tubules. The levels of vitamin A in the livers of raccoon dogs and silver foxes were extremely low, which would be interpreted as a sign of great deficiency in humans. This observation might indicate that the liver status cannot be used as an indicator of vitamin A deficiency in canines. The high levels of vitamin A in the kidneys in all three species may indicate a specific function of the kidney in the vitamin A metabolism of canines.
\end{abstract}

vitamin A / carnivore / liver / kidney / urine

Résumé - Distribution de la vitamine A et de la protéine liant le rétinol dans le plasma sanguin, l'urine, le foie et le rein de carnivores. Les concentrations en rétinol et rétinyl esters et en protéine liant le rétinol (PLR) dans le plasma, l'urine, le foie et le rein de chiens, de ratons laveurs et de

* Correspondence and reprints

Tel.: (49) 33200885 32; fax: (49) 33200885 73; e-mail: jraila@rz.uni-potsdam.de 
renards argentés ont été mesurées. Dans le plasma et l'urine des trois espèces, la vitamine A était présente sous forme de rétinol et de rétinyl esters. Dans le foie des chiens, les teneurs en vitamine A $\left(1376 \pm 669 \mu \mathrm{g} \cdot \mathrm{g}^{-1}\right)$ étaient significativement supérieures à celles du rein $\left(200 \pm 217 \mu \mathrm{g} \cdot \mathrm{g}^{-1}\right.$, $P<0,001)$. Cependant, les teneurs en vitamine A dans le rein de raton laveur $\left(291 \pm 146 \mu \mathrm{g} \cdot \mathrm{g}^{-1}\right) \mathrm{et}$ de renard $\left(474 \pm 200 \mu \mathrm{g} \cdot \mathrm{g}^{-1}\right)$ étaient significativement supérieures à celles du foie $\left(67 \pm 58 \mu \mathrm{g} \cdot \mathrm{g}^{-1} \mathrm{et}\right.$ $4,3 \pm 2,4 \mu \mathrm{g} \cdot \mathrm{g}^{-1}$, respectivement, $P<0,001$ pour chacune). PLR a été immunologiquement détectée dans le plasma sanguin de toutes les espèces, mais jamais dans l'urine. Dans le foie, de la PLR immunoréactive a été détectée dans les hépatocytes. Dans le rein, la PLR a été observée dans les cellules du tube contourné proximal dans toutes les espèces. Les taux de vitamine A dans le foie de ratons laveurs et de renards étaient extrêmement bas (qui pourraient être considérés comme le signe d'une déficience sévère chez l'humain), malgré la présence de rétinyl esters dans le plasma. Cette observation pourrait indiquer que le statut du foie ne peut être utilisé comme indicateur de la déficience en vitamine A chez les canidés. Les taux élevés de vitamine A dans le rein des trois espèces pourraient indiquer une fonction spécifique du rein pour le métabolisme de la vitamine A chez les canidés.

vitamine A / carnivore / foie / rein / urine

\section{INTRODUCTION}

Vitamin A plays an important role not only in vision, but also in growth and cellular differentiation [2]. Many of these effects are mediated by the action of retinoic acid on gene expression [3]. The central importance of vitamin $\mathrm{A}$ is reflected in the homeostatic regulation of the retinol concentration in plasma. Only as a consequence of vitamin A deficiency or intoxication do plasma concentrations change to an extent that enables these changes to be used diagnostically [17]. The homeostatic regulation in all species investigated so far is mediated by retinol-binding protein $(\mathrm{RBP})$, the only retinoid-specific binding protein that has been found in blood plasma [1]. Elevated retinyl ester levels in plasma are observed under conditions of acute or chronic vitamin A intoxication [14, 30] or as a postprandial consequence of vitamin A absorption [6]. Carnivores, however, differ profoundly from this observation because most canines and mustelids transport vitamin A in blood plasma not only as retinol but predominantly as retinyl esters, bound to lipoproteins [23, 25, 35]. The high levels of lipoprotein bound retinyl esters in carnivores are not homeostatically regulated as is retinol, but depend greatly on actual vitamin A intake in food $[24,26]$. Notwith- standing, the occurrence of retinyl esters in the blood plasma of canines and mustelids is not associated with any sign of vitamin A intoxication [5, 19, 23]. This reduced susceptibility of carnivores to high levels of retinyl esters in blood plasma raises questions concerning the possible regulatory mechanisms protecting carnivores. One possibility is the excretion of substantial amounts of vitamin $\mathrm{A}$ in the urine, as observed in the dog [27]. The present study, therefore, addresses the question as to whether species that belong to the order of Carnivora, such as the dog, fox and raccoon dog, canines, which are commonly held in fur farms, differ with respect to the quantitative and qualitative aspects of tissue distribution, plasma transport and urine excretion of vitamin A as well as the occurrence of retinol-binding protein in the plasma and urine, or, its distribution and cellular localisation in liver and kidney cells.

\section{MATERIALS AND METHODS}

\subsection{Sample collection}

Blood, urine and tissue samples were obtained from 9 adult dogs (Canis familiaris) of different pedigree, age and sex from 
the Institute of Veterinary-Pathology Leipzig and from 9 adult silver foxes (Vulpes vulpes) and 11 adult raccoon dogs (Nyctereutes procyonoides) of different sex during the pelting process on a local fur farm. Animals were last fed in the day before pelting. The silver foxes and raccoon dogs were fed the same basal diet formulated to meet the nutrient recommendations of the National Research Council (NRC) for adult foxes containing at least $200 \mathrm{IU}$ vitamin A per kg of body weight (BW) [16]. The silver foxes and raccoon dogs were supplemented once orally, approximately three weeks before pelting with 100000 IU of retinyl palmitate together with $10000 \mathrm{IU}$ vitamin D, $60 \mathrm{mg}$ vitamin $\mathrm{E}$ and $200 \mathrm{mg}$ vitamin C (Ursovit ${ }^{\circledR}$ ADEC, Serum-Werk Bernburg AG, Germany). Since the samples from the dogs were obtained on an opportunistic basis from the Department of Pathology, there was no knowledge about their nutritional status. Based on the average vitamin A concentration found in commercial dog food, the estimated intake guarantees the NRC recommendation of $75 \mathrm{IU}$ vitamin A per kg BW. The serum was prepared by centrifugation of the blood $(1500 \times g, 10 \mathrm{~min}$, $4{ }^{\circ} \mathrm{C}$ ) within $4-6 \mathrm{~h}$ after acquisition. Urine was obtained by puncture of the bladder after the pelting of the animals. Urine sediment was removed by brief centrifugation $(2 \mathrm{~min})$ at $100 \times \mathrm{g}$. Serum and urine were stored under nitrogen at $-20^{\circ} \mathrm{C}$ until needed for analysis. Tissue samples from the livers and kidneys were frozen in liquid nitrogen and kept at $-80^{\circ} \mathrm{C}$ until needed for analysis. Analyses of all samples were performed within two to four months after acquisition.

\subsection{Determination of vitamin A in blood plasma, urine and tissue samples}

Retinol and retinyl esters were determined using a gradient reversed-phase HPLC-system as previously described [28]. Briefly, vitamin A was extracted from plasma, urine and tissue samples and separated on an Inertsil-ODS column $(5 \mu \mathrm{m}$, $250 \times 4 \mathrm{~mm}$; Grom, Germany) using acetonitrile:methanol (85/15; v/v; 0.01\% ammonium acetate) and isopropanol as eluent at a flow rate of $1 \mathrm{~mL} \cdot \mathrm{min}^{-1}$. Retinol, retinyl palmitate/oleate (both could not be separated under any circumstances) and retinyl stearate were identified by comparison of retention time with external standards using a photodiode array detector (Model 996, Waters, Eschborn, Germany). Retinol and retinyl esters were quantified by measuring the absorption at $325 \mathrm{~nm}$ and calculated as retinol equivalents [21]. Recovery was $>95 \%$ for all components. The detection limit for retinol and retinyl palmitate was 2.0 and $2.4 \mathrm{ng}$, respectively. The within-day coefficient was $\pm 2.1 \%$ and $\pm 4.6 \%$ and between-day coefficient $\pm 3.0 \%$ and $\pm 9.1 \%$ for retinol and retinyl palmitate, respectively. Results were compared with regard to retinol to standard reference material 968a (Natl. Inst. Standards Technology, Gaithersburg, USA).

\subsection{Detection of RBP in blood plasma, urine and tissue samples}

Aliquots of $5 \mu \mathrm{L}$ blood plasma and $20 \mu \mathrm{L}$ urine samples (diluted 1:50 and 1:1 in SDSmercaptoethanol buffer, respectively) were subjected to $12 \%$ sodium dodecyl sulfatepolyacrylamide gel electrophoresis (SDSPAGE) according to the method of Laemmli [10]. Five microlitre aliquots of Biorad kaleidoscope prestained standards (Biorad Catalogue Number 161-0324) were also run as molecular weight standards. After gel electrophoresis, the separated proteins were electroblotted onto a polyvinylidene difluoride (PVDF) membrane (Immobilon-P Transfer Membrane, Millipore Corp., Bedford, USA) and Tris-buffered saline, $0.01 \%$ Tween 20 (TBST, pH 7.6) containing 5\% defatted milk was used to block nonspecific binding sites on the blot. The membrane was incubated 
with a 1:300 diluted peroxidase labelled rabbit anti-human serum retinol-binding protein antibody (Dako Diagnostica, Hamburg, Germany), which cross-reacted with dog $\mathrm{RBP}$ at $4{ }^{\circ} \mathrm{C}$ overnight. RBP was detected using the Luminol reaction (BM Chemiluminescence Blotting Substrate, Boehringer Mannheim, Germany). For livers and kidneys, cytosolic fractions were run on SDSPAGE and blotted onto a PVDF membrane. Blotted samples of livers and kidneys probed with a peroxidase labelled rabbit anti-human serum retinol-binding protein antibody showed a band at $21 \mathrm{kDa}$ (data not presented).

\subsection{Immunohistological investigations}

The immunolocalisation of RBP was performed in tissue sections from the liver and kidney fixed in $4 \%$ formaldehyde solution. The samples were dehydrated through graded series (50-96\%) of ethanol, embedded in paraplast, sectioned at 2-4 $\mu \mathrm{m}$ and mounted on glass slides (Super-Frost ${ }^{\circledR}, \mathrm{Fa}$. Menzel, Braunschweig, Germany). The RBP was localised by means of the peroxidase anti-peroxidase method [32]. The slides were deparaffinised, rehydrated in a decreased series of alcohol to water and incubated for $45 \mathrm{~min}$ in $0.5 \%$ hydrogen peroxide in methanol in order to deactivate endogenous peroxidases. Non-specific antibody binding was blocked for $10 \mathrm{~min}$ in Tris-buffered saline (TBS, pH 7.6), containing 50\% normal porcine serum. The sections were incubated with the primary rabbit anti-human serum retinol-binding protein ( $1: 400$ in $20 \%$ porcine serum in TBS; Dako, Hamburg, Germany). The incubation was performed in a humidified chamber (Cover plates ${ }^{\circledR}$, Shandon Life Sciences Int., Frankfurt/M., Germany) at $4{ }^{\circ} \mathrm{C}$ overnight. The sections were then incubated with swine anti-rabbit $\operatorname{IgG}$ ( $1: 100$ in $20 \%$ porcine serum in TBS) for $30 \mathrm{~min}$ and finally with a rabbit peroxidase anti-peroxidase complex (1:100 in $20 \%$ porcine serum in TBS) for $30 \mathrm{~min}$.
The sections were washed several times with TBS between each incubation. A solution of diaminobenzidine tetrahydrochloride (DAB, Fluka, Germany) and $0.01 \%$ hydrogen peroxide were used in $0.1 \mathrm{M}$ imidazole buffer ( $\mathrm{pH}$ 7.1) as substrates for the peroxidase reaction to produce the brown stain that revealed the presence of immunoreactive substances in the sections. The sections were washed three times in TBS followed by distilled water and counterstained with Papanicolaou hematoxylin. Finally, the slides were dehydrated with an increased alcohol line and covered. In control sections, normal rabbit serum was used instead of the primary antibody. All incubations except for the primary antibody were performed at room temperature.

\subsection{Statistical analysis}

Mean and standard deviations are used throughout. The statistical significance of differences between vitamin A concentrations in liver and kidney samples was assessed by the Student t-test assuming a confidence level of $P<0.05$.

\section{RESULTS}

\subsection{Retinol and retinyl esters in blood plasma and urine}

The concentrations of vitamin A in the blood plasma and urine of dogs, silver foxes and raccoon dogs are summarised in Table I. In the blood plasma of all three species, vitamin A was present as retinol, retinyl oleate/palmitate and stearate. Retinol was the predominant form of vitamin $\mathrm{A}$ in dogs and raccoon dogs $(66 \pm 27 \%$ and $70 \pm 15 \%$ of total vitamin A, respectively), while in the blood plasma of silver foxes, retinyl esters, mainly as retinyl stearate, dominated with $57 \pm 14 \%$. In the blood plasma of both dogs and silver foxes, retinyl stearate dominated over retinyl oleate/palmitate, while 
Table I. Retinol and retinyl ester concentrations in the blood plasma and urine of dogs, silver foxes and raccoon dogs $\left(\mu \mathrm{g} \cdot \mathrm{mL}^{-1}\right.$, mean $\left.\pm \mathrm{SD}\right)$.

\begin{tabular}{lccccc}
\hline & $n$ & $\begin{array}{c}\text { Total } \\
\text { vitamin A }\end{array}$ & Retinol & $\begin{array}{c}\text { Retinyl oleate/ } \\
\text { palmitate }^{\mathrm{a}}\end{array}$ & $\begin{array}{c}\text { Retinyl- } \\
\text { stearate }^{\mathrm{a}}\end{array}$ \\
\hline $\begin{array}{l}\text { Blood plasma } \\
\text { Dog }\end{array}$ & 8 & $1.82 \pm 1.21$ & $0.91 \pm 0.37$ & $0.40 \pm 0.46$ & $0.45 \pm 0.63$ \\
$\quad \begin{array}{l}\text { Silver fox } \\
\text { Raccoon dog }\end{array}$ & 9 & $1.89 \pm 1.16$ & $0.68 \pm 0.18$ & $0.45 \pm 0.29$ & $0.70 \pm 0.71$ \\
Urine & 11 & $1.88 \pm 0.33$ & $1.30 \pm 0.30$ & $0.29 \pm 0.19$ & $0.23 \pm 0.17$ \\
$\quad$ Dog & 8 & $0.44 \pm 0.55$ & $0.22 \pm 0.04$ & $0.21 \pm 0.39$ & $0.006 \pm 0.008$ \\
Silver fox & 9 & $1.72 \pm 1.35$ & $1.11 \pm 1.06$ & $0.49 \pm 0.29$ & $0.02 \pm 0.01$ \\
Raccoon dog & 4 & $2.08 \pm 0.23$ & $0.01 \pm 0.006$ & $1.86 \pm 0.18$ & $0.11 \pm 0.04$ \\
\hline
\end{tabular}

${ }^{a}$ Retinyl esters are calculated as retinol equivalents [21].

in raccoon dogs these two retinyl esters were present in equal amounts.

In the urine of dogs, raccoon dogs and silver foxes, vitamin A was present as retinol, and in the case of retinyl esters, predominantly as retinyl oleate/palmitate. Retinyl stearate was only found in traces. The predominant vitamin A compound in the urine of dogs and silver foxes was retinol $(52 \pm 35 \%$ and $59 \pm 13 \%$ of total vitamin A, respectively) and in raccoon dogs retinyl oleate/palmitate $(89 \pm 1 \%)$.

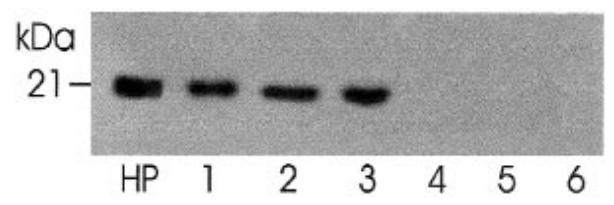

Figure 1. Immunoblot analysis of retinol-binding protein $(\mathrm{RBP})$ in human and canine plasma. Five micrograms of serum protein and three micrograms of urine protein, respectively, were subjected to $12 \%$ SDS-PAGE, transferred to a PVDF membrane and incubated with polyclonal rabbit $\operatorname{IgG}\left(1.3 \mu \mathrm{g} \cdot \mathrm{mL}^{-1}\right)$ directed against human serum RBP. Bound IgG was detected with the chemiluminescence reaction. Human plasma (HP); lane 1, plasma dog; lane 2, plasma raccoon dog; lane 3, plasma silver fox; lane 4, urine dog; lane 5, urine raccoon dog; lane 6, urine silver fox.

\subsection{RBP in blood plasma and urine}

SDS-polyacrylamide gel electrophoresis of plasma samples in combination with immunological detection of RBP after Western-blotting produced a band with a molecular weight of approximately $21 \mathrm{kDa}$ (Fig. 1, lanes 1-3). RBP was not immunologically detected in any of the urine samples obtained from the dogs, silver foxes and raccoon dogs (Fig. 1, lanes 4-6).

\subsection{Retinol and retinyl esters as well as RBP in liver and kidneys}

The results concerning the concentration of vitamin $\mathrm{A}$ in the liver and kidneys are presented in Table II. In both tissues of all three species, vitamin A was present as retinol, retinyl oleate/palmitate and stearate. In both the liver and kidneys, retinyl esters, mainly as retinyl oleate/palmitate, were predominant (85-94\% of total vitamin A) compared to retinol. In the liver, the vitamin A concentrations in raccoon dogs and particularly in silver foxes were significantly lower than the vitamin A concentration of dogs $(P<0.001)$. Considerable amounts of vitamin A were also detected in dog kidneys. However, the concentrations of vitamin A in kidneys of raccoon dogs and silver 
Table II. Retinol and retinyl ester concentrations in the livers and kidneys of dogs, silver foxes and raccoon dogs $\left(\mu \mathrm{g} \cdot \mathrm{g}^{-1}\right.$ wet tissue, mean $\left.\pm \mathrm{SD}\right)$.

\begin{tabular}{|c|c|c|c|c|c|}
\hline & $n$ & $\begin{array}{c}\text { Total } \\
\text { vitamin A }\end{array}$ & Retinol & $\begin{array}{l}\text { Retinyl oleate/ } \\
\text { palmitate }^{\mathrm{a}}\end{array}$ & $\begin{array}{l}\text { Retinyl } \\
\text { stearate }^{\mathrm{a}}\end{array}$ \\
\hline \multicolumn{6}{|l|}{ Liver } \\
\hline Dog & 9 & $1376 \pm 669$ & $171 \pm 157$ & $899 \pm 524$ & $89.4 \pm 33.4$ \\
\hline Silver fox & 7 & $4.30 \pm 2.42$ & $0.52 \pm 0.14$ & $1.99 \pm 1.45$ & $1.58 \pm 0.86$ \\
\hline Raccoon dog & 11 & $67.3 \pm 58.9$ & $2.85 \pm 2.72$ & $44.1 \pm 39.3$ & $15.3 \pm 16.3$ \\
\hline \multicolumn{6}{|l|}{ Kidney } \\
\hline $\operatorname{Dog}^{\mathrm{b}}$ & 9 & $200 \pm 217$ & $56.8 \pm 39.3$ & $128 \pm 161$ & $6.7 \pm 13.1$ \\
\hline Silver fox ${ }^{\mathrm{b}}$ & 7 & $474 \pm 200$ & $64.5 \pm 73.2$ & $381 \pm 160$ & $18.9 \pm 13.6$ \\
\hline Raccoon dog $\mathrm{c}$ & 11 & $291 \pm 146$ & $9.9 \pm 5.3$ & $245 \pm 127$ & $22.9 \pm 11.6$ \\
\hline
\end{tabular}

${ }^{a}$ Retinyl esters are calculated as retinol equivalents [21].

${ }^{b}$ Cortex.

c Total organ

foxes were higher (4-fold and 100-fold, respectively) compared to the liver levels in these species $(P<0.001)$.

In the three species investigated, the distribution of immunoreactive RBP showed a very similar cellular distribution in the liver as well as in the kidneys. Therefore, the results are presented as representative pictures obtained from the silver fox. In the liver (Fig. 2A), a specific cytoplasmic staining for RBP was observed in the parenchymal cells (hepatocytes). Periportal intensity was much stronger than centrolobular intensity. In the kidneys (Fig. 3A), a strong staining for RBP was observed exclusively in the proximal convoluted tubular cells of the cortex. Sections incubated without primary antibody (Figs. 2B and 3B) showed no labelling.

\section{DISCUSSION}

\subsection{Vitamin A transport in blood plasma}

Plasma vitamin A concentrations in the species investigated were much higher than in humans, ruminants, horses or rodents, but were in general agreement with data previously reported for canines and mustelids $[19,25]$. The higher plasma concentrations are due to a high percentage of retinyl esters, which are bound to lipoproteins of very low, low and high density (VLDL, LDL, HDL) in the blood plasma of canines [23, 35]. This might indicate that the majority of these retinyl esters in canine plasma are of hepatic and not intestinal origin [15]. The observed differences between the species with regard to the relative contribution of the individual retinyl esters to total vitamin A might be species specific or could possibly be attributed to differences in feeding. Indirect evidence for this possibility can be deduced from this study and from a recent feeding trial, since retinyl ester values showed a much higher variation compared to retinol, which is only slightly affected by the dietary amount of vitamin A [24]. This consistency shows that the retinol levels in canines are as homeostatically regulated as in other species. Since our study shows that in all the species investigated RBP was present in the plasma, this specific binding protein for retinol may be involved in the regulation of retinol levels in canines as in other species.

\subsection{Tissue distribution of vitamin A and RBP}

The liver, the major site of vitamin A storage, is the tissue that contributes 

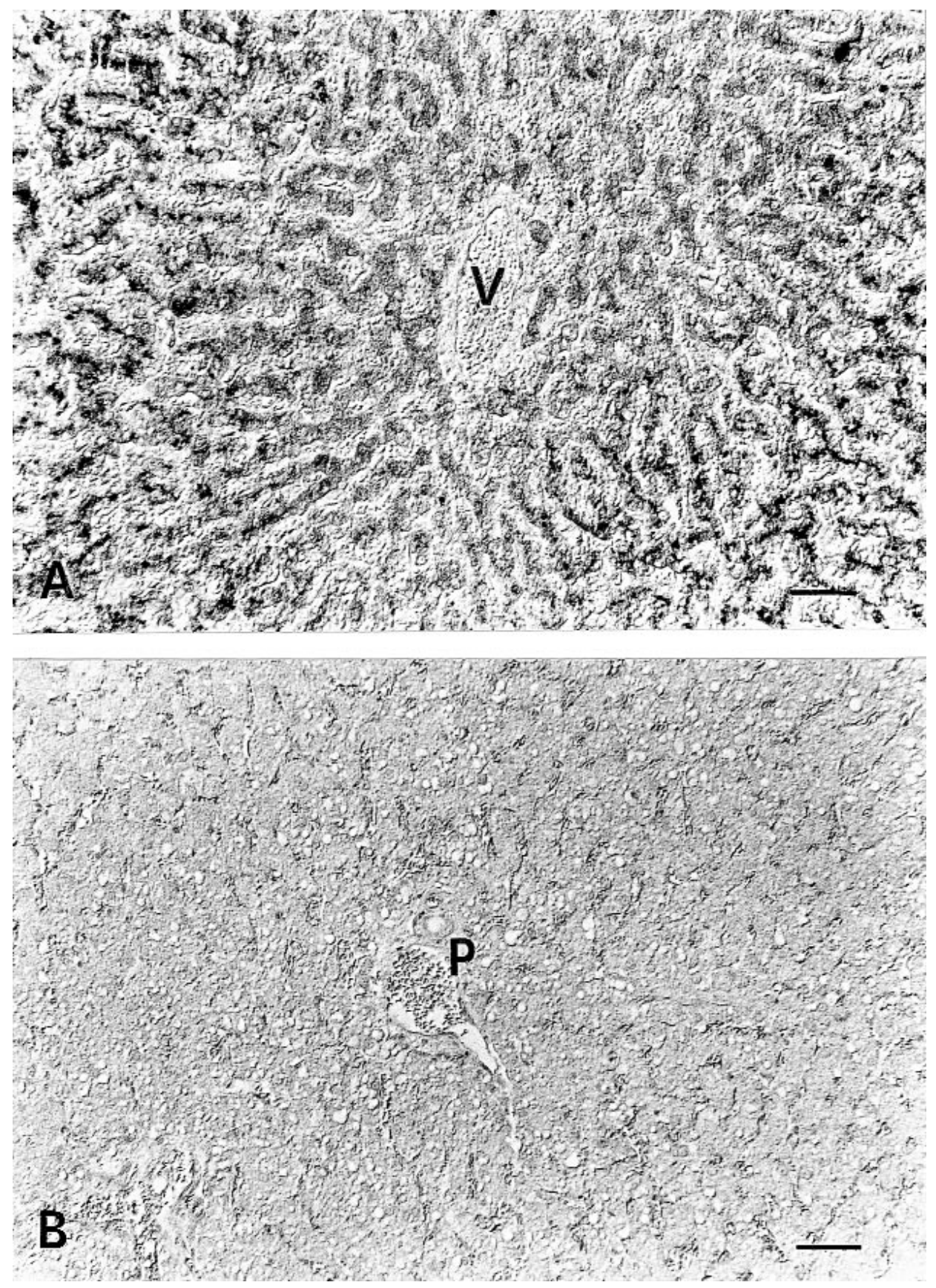

Figure 2. (A) Localisation of immunoreactive RBP in silver fox liver. Cytoplasmic staining of the perivenous parenchymal cells is less intensively than periportal reaction; Vena centralis (V). (B) Section incubated without primary antibody shows no labelling. Portal triad (P) consisted of Vena portae, Arteria hepatica and bile duct. (Immunohistology, Nomarski interference contrast; scale bar $40 \mu \mathrm{m}$ ). 

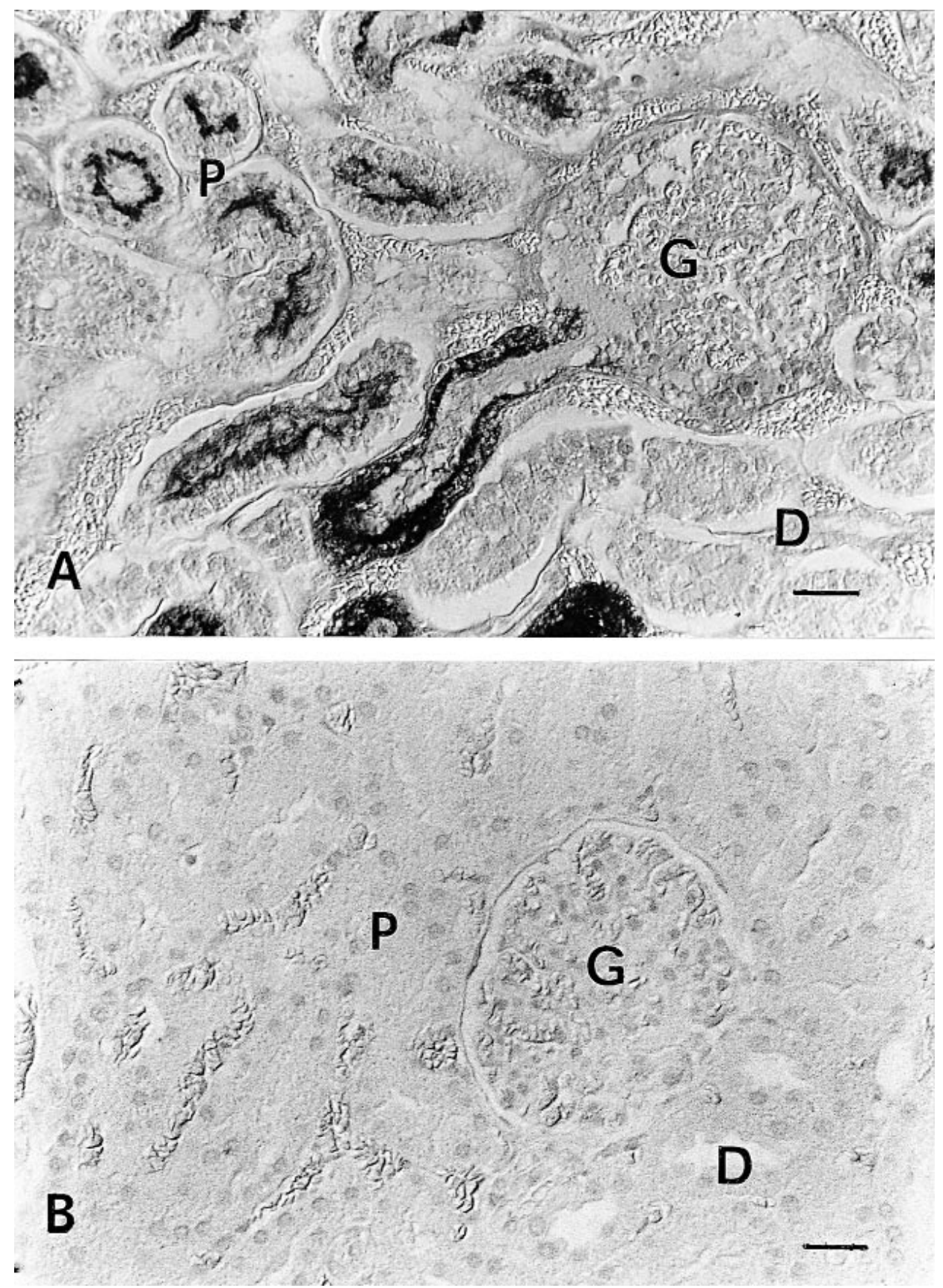

Figure 3. (A) Localisation of immunoreactive RBP in silver fox kidney. Strong reaction of proximal convoluted tubular cells (P). Glomerulus (G), Henle loop, distal tubular cells (D) and collecting tubule react negatively. (B) Section incubated without primary antibody shows no labelling (Immunohistology, Nomarski interference contrast; scale bar $20 \mu \mathrm{m})$. 
substantially to the plasma vitamin A levels in carnivores. This assumption is based on the observation of immunoreactive RBP in the livers of dogs, foxes and raccoon dogs and the observation that in dogs, foxes and ferrets, the retinyl esters in plasma are associated with all three lipoprotein fractions. Vitamin A contents in the livers of dogs are reported, in accordance with our results, to be much higher compared to the vitamin A levels in the livers of humans, rats, pigs or cattle, but are lower than those in polar bear liver $[12,13,18,20]$. In contrast to dogs, the levels of vitamin A in the livers of raccoon dogs and silver foxes were comparable or even much lower than in non-carnivorous species, although the two species were fed according to NRC requirements and additionally substituted with vitamin $\mathrm{A}$. In silver foxes, vitamin A in the liver is present in such low concentrations that the values would be interpreted in humans as severely deficient [17]. Such low vitamin A levels are associated with a substantial reduction in plasma retinol and severe signs of vitamin A deficiency $[17,33]$. But despite these low liver levels, retinol and retinyl esters in blood plasma were similar, and values in kidneys and urine of silver foxes and raccoon dogs were substantially higher than those observed in dogs in which vitamin A levels in the liver were nearly 300-fold higher than in silver foxes. Based on these observations, further investigations will be required in order to establish whether similar minimal adequate reserves for vitamin A can be used to interpret the vitamin A status of canines as is the case in humans or other species such as rats, rabbits and pigs $[17,33]$. Despite obvious quantitative differences in the concentrations of vitamin A in the livers of dogs, raccoon dogs and silver foxes, immunohistochemistry of RBP showed a similar pattern in its distribution and intensity of staining within liver parenchymal cells. This is of interest, since one factor that specifically regulates RBP secretion from the liver is the nutritional vitamin A status of the animal. In rats, vita- min A deficiency blocks the secretion of RBP from the liver, so that plasma RBP concentrations fall and liver RBP levels rise $[1,7]$. These observations are consistent with a much stronger intensity of staining for immunoreactive RBP in the liver of vitamin A deficient rats [9].

The kidneys play an important role in vitamin A metabolism in the recycling of RBP-retinol [4, 7]. Consequently, immunoreactive $\mathrm{RBP}$ could be detected in the proximal convoluted tubules as described in human and rat kidneys $[8,9]$. This result and the high vitamin A concentrations in the kidneys of raccoon dogs and silver foxes despite low vitamin A concentrations in the livers suggest a specific function of the canine kidney in contributing plasma retinol and retinyl esters in addition to the excretion of vitamin A with the urine [27].

\subsection{Urinary vitamin A excretion}

It is now well established that carnivores do excrete substantial amounts of retinol and retinyl esters with the urine [24, 28]. Causes and consequences of this unique phenomenon, however, are yet unknown. In humans and rats, vitamin A is only excreted with the urine as metabolized retinol compounds, such as retinoic acid isomers or retinoyl glucuronides [11, 22, 34]. The excretion of retinol has only been observed in humans suffering from severe infections as the result of a decreased protein reabsorption by the tubular epithelium during febrile proteinuria [31]. The results of this study extend the observation of vitamin A excretion to silver foxes and raccoon dogs and suggest that the excretion of vitamin $A$ in the urine of carnivores is not affected by the vitamin A status of the animal itself. Even in silver foxes, in which vitamin A levels in the liver would be interpreted as deficient, vitamin A concentrations in the urine of dogs and silver foxes were comparable. A recent feeding trail indicates that the excretion may not be affected 
by the vitamin A status of the animal but by the amount of vitamin A available through the diet. If dogs are fed above NRC requirements (75 IU Vitamin A per kg body weight) vitamin $\mathrm{A}$ is observed in the urine, but as soon as the dietary concentration of vitamin A is reduced to levels at or below NRC requirements, only trace amounts of vitamin A are excreted in the urine [24]. This supports the hypothesis that in dogs, the excretion of vitamin A with the urine is regulated and not merely a passive process depending on the concentration of vitamin A in the blood plasma. Based on this study RBP can be excluded as a carrier for retinol and/or retinyl esters in the urine. Previous studies showed that retinol and retinyl esters are associated with a complex that behaves like a lipoprotein [27]. Recently we were able to purify the protein moiety of this vitamin A-protein complex to homogeneity and furthermore characterise this protein as a Tamm-Horsfall like glycoprotein [29]. Causes and consequences of this unique phenomenon are unknown, but based on our observations that urinary vitamin $\mathrm{A}$ is associated with a protein exclusively synthesised in kidney cells, some yet to be determined mechanism regulating the excretion of vitamin $\mathrm{A}$ in the urine of canine might exist.

\section{ACKNOWLEDGEMENTS}

We would like to thank Dr. U.D. Wenzel for providing the raccoon dog and silver fox samples and Mrs. A. Hurtienne and E. Pilz for their technical assistance in the HPLC and Western blot analysis. The study was supported by the Gesellschaft zur Förderung Kynologischer Forschung, Germany. Jens Raila, DVM received a grant from the Hanns-Seidel-Stiftung München, Germany.

\section{REFERENCES}

[1] Blaner W.S., Retinol-binding protein: the serum transport protein for vitamin A, Endocr. Rev. 10 (1989) 308-316
[2] Blomhoff R., Introduction: Overview of vitamin A metabolism and function, in: Blomhoff R. (Ed.), Vitamin A in Health and Disease, Marcel Dekker, Inc., New York, Basel, Hong Kong, 1994, pp. 1-35.

[3] Chambon P., A decade of molecular biology of retinoic acid receptors, FASEB J. 10 (1996) 940954.

[4] Christensen E.I., Moskaug J.O., Vorum H., Jacobsen C., Gundersen T.E., Nykjaer A., Blomhoff R., Willnow T.E., Moestrup S.K., Evidence for an essential role of megalin in transepithelial transport of retinol, J. Am. Soc. Nephrol. 10 (1999) 685-695.

[5] Cline J.L., Czarnecki-Maulden G.L., Losonsky J.M., Sipe C.R., Easter R.A., Effect of increasing dietary vitamin A on bone density in adult dogs, J. Anim. Sci. 75 (1997) 2980-2985.

[6] Eckhoff C., Collins M.D., Nau H., Human plasma all-trans-, 13-cis- and 13-cis-4-oxoretinoic acid profiles during subchronic vitamin A supplementation: comparison to retinol and retinyl ester plasma levels, J. Nutr. 121 (1991) 1016-1025.

[7] Goodman D.S., Plasma Retinol-binding Protein, in: Sporn M.B., Roberts A.B., Goodman D.S. (Eds.), The Retinoids, Academic Press, Vol. 2, Orlando, FL, 1984, pp. 41-88.

[8] Kato M., Kanai M., Kameko M., Ohno S., Fuijii Y., Nagata T., Localization of retinol-binding protein and prealbumin in the human kidney with an unlabeled immunohistochemical method, Acta Histochem. Cytochem. 15 (1982) 68-75.

[9] Kato M., Kato K., Goodman D.S., Immunocytochemical studies on the localization of plasma and of cellular retinol-binding proteins and of transthyretin (prealbumin) in rat liver and kidney, J. Cell Biol. 98 (1984) 1696-1704.

[10] Laemmli U.K., Cleavage of structural proteins during the assembly of the head of bacteriophage T4, Nature 227 (1970) 680-685.

[11] Lambert W.E., De Leenheer A.P., Demonstration of retinoic acid isomers in human urine under physiological conditions, Experientia 41 (1985) 359-360.

[12] Landes E., Die Konzentration von Vitamin A in der Leber von Rindern und Schweinen, Uebersichten zur Tierernaehrung 22 (1994) 281-320.

[13] Lewis R.W., Lentfer J.W., The vitamin A content of polar bear liver: range and variability, Comp. Biochem. Physiol. 22 (1967) 923-926.

[14] Mallia A.K., Smith J.E., Goodman D.W. Metabolism of retinol-binding protein and vitamin A during hypervitaminosis A in the rat, J. Lipid Res. 16 (1975) 180-188.

[15] Melchior G.W., Mahley R.W., Buckhold D.K., Chylomicron metabolism during dietary-induced hypercholesterolemia in dogs, J. Lipid Res. 22 (1981) 598-609.

[16] National Research Council, Nutrient requirements of domestic animals: Nutrient requirements of 
minks and foxes, National Academy of Sciences, National Research Council, Washington D.C., USA, 1968.

[17] Olson J.A., Serum levels of vitamin A and carotenoids as reflectors of nutritional status, J. Natl. Cancer Inst. 73 (1984) 1439-1444.

[18] Raica N. Jr., Scott J., Lowry L., Sauberlich H.E., Vitamin A concentration in human tissues collected from five areas in the United States, Am. J. Clin. Nutr. 25 (1972) 291-296.

[19] Ribaya-Mercado J.D., Blanco M.C., Fox J.G., Russell R.M., High concentrations of vitamin A esters circulate primarily as retinyl stearate and are stored primarily as retinyl palmitate in ferret tissues, J. Am. Coll. Nutr. 13 (1994) 83-86.

[20] Rosales F.J., Ritter S.J., Zolfaghari R., Smith J.E., Ross A.C., Effects of acute inflammation on plasma retinol, retinol-binding protein, and its mRNA in the liver and kidneys of vitamin A-sufficient rats, J. Lipid Res. 37 (1996) 962-971.

[21] Ross A.C., Separation of long-chain fatty acid esters of retinol by high-performance liquid chromatography, Anal. Biochem. 115 (1981) 324330.

[22] Sass J.O., Masgrau E., Saurat J.H., Nau H., Metabolism of oral 9-cis-retinoic acid in the human. Identification of 9-cis-retinoyl-beta-glucuronide and 9-cis-4-oxo-retinoyl-beta- glucuronide as urinary metabolites, Drug Metab. Dispos. 23 (1995) 887-891.

[23] Schweigert F.J., Insensitivity of dogs to the effects of nonspecific bound vitamin A in plasma, Int. J. Vitam. Nutr. Res. 58 (1988) 23-25.

[24] Schweigert F.J., Bok V., Vitamin A in blood plasma and urine of dogs is affected by dietary level of vitamin A, Int. J. Vitam. Nutr. Res. 70 (2000) 84-91.

[25] Schweigert F.J., Ryder O.A., Rambeck W.A., Zucker H., The majority of vitamin A is transported as retinyl esters in the blood of most carnivores, Comp. Biochem. Physiol. A 95 (1990) 573-578.
[26] Schweigert F.J., Uehlein-Harrell S., Zucker H., Effect of feeding on vitamin A concentrations in blood plasma of dogs, Zentralbl. Veterinaermed. A 37 (1990) 605-609.

[27] Schweigert F.J., Thomann E., Zucker H., Vitamin A in the urine of carnivores, Int. J. Vitam. Nutr. Res. 61 (1991) 110-113.

[28] Schweigert F.J., Buchholz I., Bonitz K., Effect of age on the levels of retinol and retinyl esters in blood plasma, liver and kidney of dogs, Int. J. Vitam. Nutr. Res. 68 (1998) 237-241.

[29] Schweigert F.J., Raila J., Haebel S., Vitamin A excretetd in urine of canines is associated with a Tamm-Horsfall like protein, Biol. Chem. Hoppe Seyler 379 (1998) S128.

[30] Smith F.R., Goodman D.S., Vitamin A transport in human vitamin A toxicity, N. Engl. J. Med. 294 (1976) 805-808.

[31] Stephensen C.B., Alvarez J.O., Kohatsu J., Hardmeier R., Kennedy J.I. Jr., Gammon R.B. Jr., Vitamin A is excreted in the urine during acute infection, Am. J. Clin. Nutr. 60 (1994) 388392.

[32] Sternberger L.A., Hardy P.H. Jr., Cuculis J.J., Meyer H.G., The unlabeled antibody enzyme method of immunohistochemistry: preparation and properties of soluble antigen-antibody complex (horseradish peroxidase-antihorseradish peroxidase) and its use in identification of spirochetes, J. Histochem. Cytochem. 18 (1970) 315-333.

[33] Underwood B.A., Methods for assessment of vitamin A status, J. Nutr. 120 (1990) 1459-1463.

[34] Varma R.N., Beaton G.H., Quantitative aspects of the urinary and fecal excretion of radioactive metabolites of vitamin A in the rat, Can. J. Physiol. Pharmacol. 50 (1972) 1026-1037.

[35] Wilson D.E., Hejazi J., Elstad N.L., Chan I.F., Gleeson J.M., Iverius P.H., Novel aspects of vitamin A metabolism in the dog: distribution of lipoprotein retinyl esters in vitamin A-deprived and cholesterol-fed animals, Biochim. Biophys. Acta 922 (1987) 247-258. 